DOI: $10.38136 /$ jgon. 857146

\title{
The role of neutrophil/lymphocyte ratio and mean platelet volume in diagnosis of ovarian torsion.
}

\section{Over torsiyonu tanısında nötrofil/lenfosit oranı ve ortalama trombosit hacminin rolü}

\author{
AyșegüL ÖKSÜZOĞLU
}

(1) Orcid ID:0000-0003-0042-0307

\section{${ }^{1}$ Department of Obstetrics and Gynecology, Zekai Tahir Burak Women's Health Education and Research Hospital Ankara, Turkey}

\section{ÖZ}

Amaç: Over torsiyonu, sıkıkla tanıda gecikmeye neden olan spesifik olmayan semptomlarla ortaya çıkan jinekolojik acillerden biridir. Over torsiyonunun preoperatif kesin tanısını koymada yeterli klinik, laboratuar veya görüntüleme kriteri yoktur. Bu çalı̧manın amacı, over torsiyonu tanısında nötrofil/lenfosit oranının (NLO) ve ortalama trombosit hacmi (MPV) değerinin belirleyici rolünü araştırmaktır.

Gereç ve yöntemler: Bu retrospektif çalışmaya toplam 198 kadın dahil edilerek, iki çalışma grubu oluşturuldu. Grup 1. abdominal eksplorasyon sonrası over torsiyonu tanısı alan 66 hastadan, kontrol grubu benign unrüptüre over kistleri nedeniyle opere edilen 132 hastadan oluşmaktaydı (Grup 2). Gruplar klinik özellikler ve hematolojik parametrelerine göre karşılaştırıldı Demografik ve klinik özellikler ve preoperatif tam kan sayımı parametreleri tıbbi kayıtlardan elde edildi..

Bulgular: Kontrol grubu ile karşılaştırıldığında over torsiyonlu olgularda preoperatif ortalama lökosit, nötrofil ve NLO anlamlı olarak yüksek, MPV anlamlı olarak düşüktü ( $p<0.001$ ). ROC eğrisi analizi, NLO'nun kesme değerinin\% 87,9 duyarlılık ve \% 68,2 özgüllük ile 2,68 olduğunu gösterdi. MPV düzeyi için kesme değeri 10,05 olup, duyarlilık ve özgüllük düzeyleri sırasıyla $\% 56,1$ ve $\% 80,3$ olarak bulundu.

Sonuç: Preoperatif NLR ve MPV, over torsiyonunu diğer akut karın nedenlerinden ayırt etmede yardımcı olabilir. Bu parametreler over torsiyonu tanısında öngörücü bir faktör olarak kullanılabilir.

\section{INTRODUCTION}

Ovarian torsion, is defined as the partial or complete rotation of an ovary or ovarian vascular pedicle around its long axis, resulting in ischemic changes in the ovary (1). Ovarian torsion accounts for $2-3 \%$ of gynecological emergencies (2). It can occur at any age but mainly in the reproductive age group (3). Early diagnosis of ovarian torsion is difficult and challenging. There are no clinical or imaging criteria sufficient to confirm the preoperative diagnosis of ovarian torsion. When ovarian torsion is suspected, ultrasonography is the initial diagnosis method, blood velocity loss in doppler ultrasonography is the possible

\section{ABSTRACT}

Aim: Ovarian torsion is one of the gynecological emergencies that often presents with non-specific symptoms leading to delayed diagnosis. There are no adequate clinical, laboratory or imaging criteria to make a definitive diagnosis of ovarian torsion preoperatively. The aim of this study was to investigate the role of the neutrophil to lymphocyte ratio (NLR) and mean platelet volume (MPV) value in the diagnosis of patients with ovarian torsion.

Materials and method: A total of 198 women were included in this retrospective study and two study groups were formed. Group 1 consisted of 66 patients diagnosed with ovarian torsion following abdominal exploration and the control group consisted of 132 patients who were operated for benign unruptured ovarian cysts (Group 2). Groups were compared according to clinical characteristics and hematological parameters. Demographic and clinical characteristics and preoperative complete blood count parameters were retrieved from the medical records.

Results: Mean leukocyte, neutrophil, and NLR were significantly higher, and MPV was significantly lower in patients with ovarian torsion compared to controls $(p<0.001)$. ROC curve analysis demonstrated that cut-off value of NLR was 2.68 with $87.9 \%$ sensitivity and $68.2 \%$ specificity. The cut-off value for the MPV level was $10.05 \mathrm{fL}$ and, the sensitivity and specificity levels were found to be $56.1 \%$ and $80.3 \%$, respectively.

Conclusion: NLR and MPV may be helpful to preoperatively distinguish ovarian torsion from other causes of acute abdomen. These parameters can be used as a predictive factors in the diagnosis of ovarian torsion.

finding, but the more precise diagnosis of ovarian torsion is often done intraoperatively (4). Early diagnosis and surgery have a vital role in preserving the viability of ovaries and prevent severe morbidity (5). If no surgery is performed, the ovary will become ischemic and necrotic, and thrombophlebitis, infection, and peritonitis also may occur (6). Ovarian torsion can be treated by detorsion, ovarian cystectomy and oophorectomy (7). Hematological parameters, especially the leukocyte subtypes and the ratio of these markers have been shown to play a predictive role in the diagnosis of acute and chronic inflammatory processes (8). Many studies have shown that the neutrophil to 
lymphocyte ratio (NLR) and mean platelet volume (MPV) are a significant inflammatory markers in diseases such as acute appendicitis, inflammatory bowel diseases, rheumatoid arthritis, celiac disease, acute ischemic stroke, myocardial infarction, pelvic inflammatory, ectopic pregnancy, endometriosis and malignancy (8-13).

In the diagnosis of ovarian torsion, careful examination of hematological parameters, can give us valuable information. The aim of this study was to investigate the role of the NLR and MPV value in the diagnosis of patients with ovarian torsion.

\section{MATERIALS AND METHODS}

This retrospective study compared to 66 patients with ovarian torsion and 132 patients with benign unruptured ovarian cysts who underwent surgery. All surgical procedures were performed at the Department of Gynecology, Zekai Tahir Burak Women's Health Education and Research Hospital in Ankara, between January 2014 and January 2019. The study was approved by the local Ethics Committee of the institution, and all the subjects whose data was included had furnished informed consent at the time of their surgeries (Approval Number:53)

The data of the patients were collected from hospital database sytem and patient's medical records. A total of seventy six patients with ovarian torsion were identified from the hospital records. We excluded one patient with hyperthyroidism, two patients with tubal ovarian abscess, three patients with malignancy, four patients who had incomplete laboratory data, especially blood count values; the remaining 66 patients were considered as the group 1. The control group included 132 patients who were operated for benign unruptured ovarian cysts (Group 2). The patients in the two groups were matched with respect to age and parity. Demographic and clinical characteristics, and preoperative complete blood count parameters (leukocyte, neutrophil, lymphocyte and platelet counts, MPV and NLR) were compared between the two groups. The presence of ovarian torsion or unruptured ovarian cyst was determined by ultrasound screening, computed tomography or magnetic resonance imaging in the preoperative period and by visualization during the operation. Laparoscopy was the preferred procedure in surgical management. All of the cases with torsion were managed by detorsion, with cystectomy (if ovarian cyst present) in operation. Histopathology results of all patients were recorded from the hospital database postoperatively.

Hematological parameters were performed by flow cytometry
(Beckman Coulter LH-780 Analyzer, Beckman Coulter Inc., USA) before surgical intervention from patients. All hematological parameters (leukocyte, neutrophil, lymphocyte, and platelet counts) were denominated in $103 / \mu \mathrm{L}$ except MPV. The MPV value was denominated in femtoliter. NLR was calculated by dividing the neutrophil count with the lymphocyte count.

Patients who had, endometriosis, pelvic inflammatory disease, tubo-ovarian abscess, hematological disease, a chronic systemic disease, malignancy, using anticoagulants and hormonal contraceptives, and pregnant patients were excluded from the study as their situation might affect on blood count parameters.

\section{Statistical analysis}

All statistical analyses were performed by using SPSS software, version 20.0 (Chicago, IL,USA). The descriptive data are presented as means \pm standard deviation and medians (minimum-maximum). The Kolmogorov-Smirnov test was used to determine whether the values were normally distributed. Categorical variables were expressed as numbers and percentages. The chi-square test was used to compare proportions in different groups. Student t-test or Mann-Whitney U-test was used to compare the two independent groups according to distribution. ROC curve analysis was used to assess the discriminative role of NLR and MPV. $P$ value $<0.05$ was considered significant.

\section{RESULTS}

Demographic and clinical characteristics of the cases are shown in Table 1. The mean age of groups 1 and 2 were $33.7 \pm 6.8$ years and $35.5 \pm 8.6$ years, respectively. There was no significant difference between the two groups in terms of both age, BMI, gravidity, parity, diameter of adnexal mass and location of adnexal mass $(p>0.05)$. 
Table 1. Comparison of the Demographic and Clinical Parameters Among the groups

\begin{tabular}{|c|c|c|c|}
\hline Variables & $\begin{array}{c}\text { Group } 1 \\
\text { (Ovarian Torsion) } \\
8 \quad(\mathrm{n}=66)\end{array}$ & $\begin{array}{c}\text { Group } 2 \\
\text { (Ovarian Cyst ) } \\
(\mathrm{n}=132)\end{array}$ & $P$-value \\
\hline Age (years), mean \pm SD & $33.7 \pm 6.8$ & $34.7 \pm 8.6$ & 0.147 \\
\hline BMI $\left(\mathrm{kg} / \mathrm{m}^{2}\right)$, mean \pm SD & $25.1 \pm 4.5$ & $26.9 \pm 4.8$ & 0.704 \\
\hline $\begin{array}{l}\text { Gravidity, median } \\
\text { (minimum-maximum) }\end{array}$ & $2(0-4)$ & $2(0-5)$ & 0.256 \\
\hline $\begin{array}{l}\text { Parity, median } \\
\text { (minimum-maximum) }\end{array}$ & $1(0-4)$ & $1(0-3)$ & 0.147 \\
\hline $\begin{array}{l}\text { Diameter of ad- } \\
\text { nexal mass }(\mathrm{cm}) \\
\text { mean } \pm \text { SD } \\
\end{array}$ & $74.2 \pm 25.8$ & $72.1 \pm 35.7$ & 0.744 \\
\hline $\begin{array}{l}\begin{array}{l}\text { Location of the mass, } \mathrm{n} \\
(\%)\end{array} \\
\text { Right } \\
\text { Left } \\
\end{array}$ & $\begin{array}{l}31(\% 47) \\
35(\% 53)\end{array}$ & $\begin{array}{l}63(\% 47.7) \\
69(\% 52.3)\end{array}$ & 0.920 \\
\hline Detorsion, n (\%) & $33(\% 50)$ & & \\
\hline Cystectomy, n (\%) & $21(\% 31.8)$ & $104(\% 78.7)$ & \\
\hline USO, n (\%) & $12(\% 18.2)$ & $28(\% 21.3)$ & \\
\hline
\end{tabular}

BMI, body mass index; USO, unilateral salpingooferectomy; Data are presented as mean \pm standard deviation, median (minimum-maximum), and $n(\%) ; p<0.05$ is considered statistically significant

Mean leukocyte, neutrophil counts and NLR value were significantly higher $(p<0.05)$ and the MPV was significantly lower $(p<0.05)$ in the patients with ovarian torsion than the controls. The comparison of blood parameters among the two groups is shown in Table 2.

Table 2. Comparison of the Laboratory Parameters Among the Groups

\begin{tabular}{|l|l|l|l|}
\hline \multicolumn{1}{|c|}{$\begin{array}{l}\text { Vari- } \\
\text { ables }\end{array}$} & $\begin{array}{l}\text { Group 1 } \\
\text { (Ovarian Torsion }) \\
(\mathrm{n}=66)\end{array}$ & $\begin{array}{l}\text { Grup 2 } \\
(\text { Ovarian Cyst }) \\
(\mathrm{n}=132)\end{array}$ & $P$-value \\
\hline $\begin{array}{l}\text { WBC } \\
\left(\mathrm{x} 10^{3} / \mathrm{uL}\right)\end{array}$ & $11.6 \pm 3.2$ & $8.1 \pm 3.1$ & $<0.001$ \\
\hline $\begin{array}{l}\text { Neutrophil } \\
\left(\mathrm{x} 10^{3} / \mathrm{uL}\right)\end{array}$ & $9.3 \pm 3.1$ & $5.4 \pm 2.9$ & $<0.001$ \\
\hline $\begin{array}{l}\text { Lymphocyte } \\
\left(\mathrm{x} 10^{3} / \mu \mathrm{L}\right)\end{array}$ & $1.8 \pm 0.9$ & $1.9 \pm 0.5$ & 0.219 \\
\hline $\begin{array}{l}\text { Platelet } \\
\left(\mathrm{x} 10^{3} / \mu \mathrm{L}\right)\end{array}$ & $266.6 \pm 71.7$ & $279.5 \pm 55.9$ & 0.235 \\
\hline NLR & $6.5 \pm 3.7$ & $3.4 \pm 3.2$ & $<0.001$ \\
\hline MPV $(\mathrm{fL})$ & $9.66 \pm 2.0$ & $10.69 \pm 0.9$ & $<0.001$ \\
\hline
\end{tabular}

Values are expressed as *mean \pm standard deviation WBC: White blood cell,

NLR: Neutrophil to lymphocyte ratio.

PLR: Platelet to lymphocyte ratio.

MPV: Mean platelet volume
ROC curve analysis demonstrated that increased NLR (AUC, 0.795; 95\% Cl: 0.730-0.860; $\mathrm{p}<0.001)$ and decreased MPV (AUC, $0.708 ; 95 \% \mathrm{Cl}: 0.624-0.792 ; p<0.001$ ) are the statistically significant discriminative factors in predicting ovarian torsion in patients preoperatively. These results is shown in Fig.1 and Fig.2. Additionally, the cut-off values, sensitivity, specificity, positive predictive value, and negative predictive value of these hematological parameters in predicting ovarian torsion diagnosis are shown in Table 3.

Figure 1. ROC Curve Analysis for NLR in Prediction of Ovarian Torsion

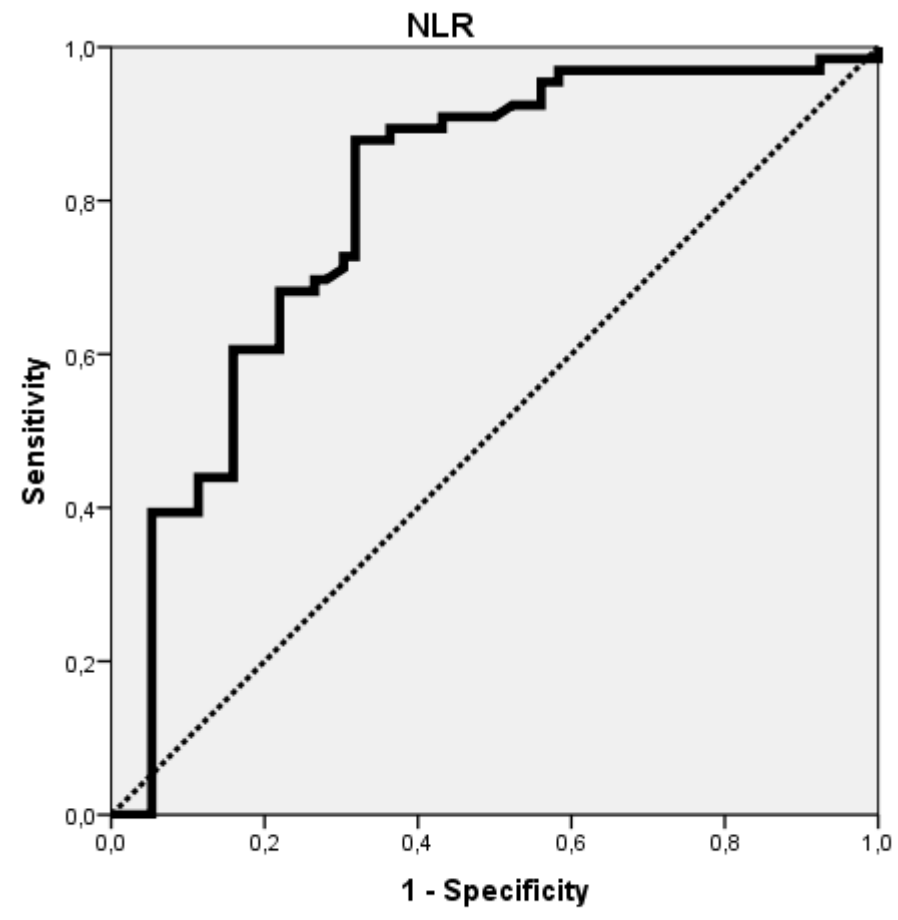

Diagonal segments are produced by ties.

Figure 2. ROC Curve Analysis for MPV in Prediction of Ovarian Torsion

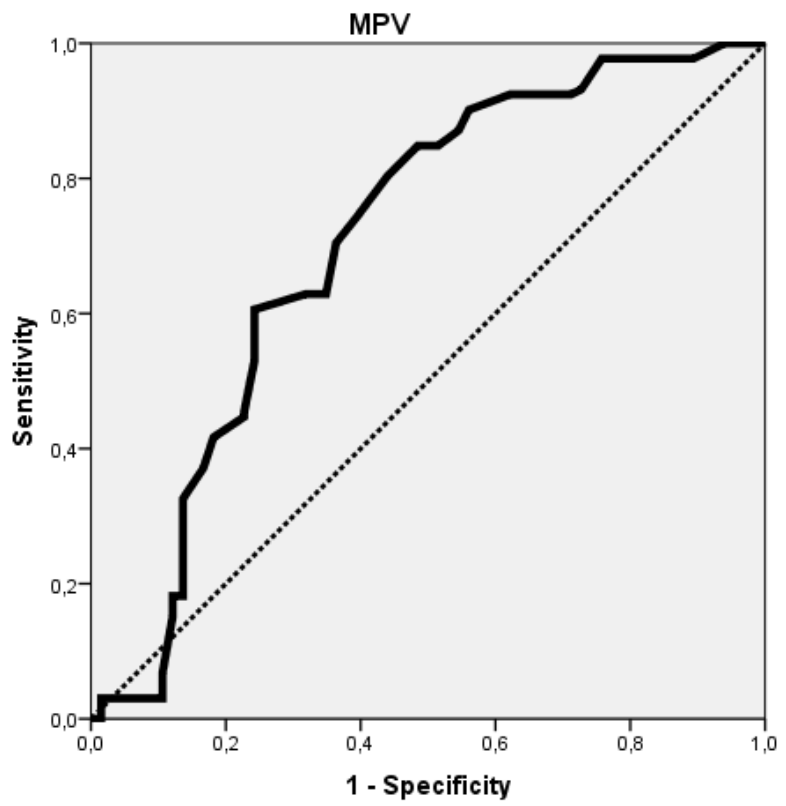

Diagonal segments are produced by ties. 
Table 3. Prediction of ovarian torsion according to the cutoff values of NLR and MPV

\begin{tabular}{|l|l|l|l|l|l|l|}
\hline Parameter & Cutoff value & Sensitivity (\%) & Specificity (\%) & PPV (\%) & NPV (\%) & $P$-value \\
\hline NLR & 2,68 & 87,9 & 68,2 & 58,0 & 91,8 & 0,001 \\
\hline MPV & 10,05 & 56,1 & 80,3 & 58,7 & 78,5 & 0,001 \\
\hline
\end{tabular}

NLR, neutrophil to lymphocyte ratio; MPV, mean platelet volume; PPV, positive predictive value; NPV, negative predictive value. P<0.05 was considered statistically significant.

When the cut-off point for the NLR level was set to 2.68, the sensitivity and specificity levels were found to be $87.9 \%$ and $68.2 \%$, respectively. When the cut-off point for the MPV level was set to 10.05 , the sensitivity and specificity levels were found to be $56.1 \%$ and $80.3 \%$, respectively.

\section{Discussion}

Ovarian torsion, one of the gynecological emergencies, is an uncommon cause of acute lower abdominal pain in females. Diagnosis can be difficult, particularly in intermittent torsion and the differential diagnosis can include several other gynecological and surgical emergencies. Although inflammation markers and imaging methods are commonly used in the diagnosis of ovarian torsion, it is difficult to make differential diagnosis from other causes of acute abdomen due to non-specific abdominal symptoms.

Recently, several studies have shown that the NLR and MPV have potential as a marker of gynecologic inflammatory disorders and malignancies such as endometriosis, pelvic inflammatory disease, adnexal torsion, preterm birth, ovarian cancer, cervical cancer, gestational trophoblastic disease, endometrial hyperplasia, gestational diabetes, and preeclampsia (14-16).

In systemic inflammation caused by ischemia, it is known that neutrophil count increases and lymphocyte count decreases. The NLR, the ratio of neutrophil to lymphocyte, is a simple marker of the inflammatory response, reflecting the adequacy of the cellular immune response against the extent of systemic inflammation resulting from ischemia. It can be considered as a sensitive and specific marker and used as a diagnostic marker of various ischemic diseases (17). A recent study reported that high NLR values were significantly associated with adnexal torsion. In this study, it was suggested that the high NLR values are caused by an inflammatory response to ischemia, which causes an increase in neutrophil and a decrease in lymphocyte counts (18). Our results were in accordance with this recently published study in which adnexal torsion was associated with higher NLR value.
Ercan et al. compared preoperative NLR and WBC counts in patients with adnexal torsion and ovarian cysts. While WBC and neutrophil counts were high in both groups, NLR was significantly higher in the adnexal torsion group (19). Soysal et al. compared the hematological parameters of patients with adnexal torsion with those of patients with ruptured and unruptured ovarian cysts. They found that NLR had no diagnostic value for the differentiation of ruptured ovarian cysts from adnexal torsion, but found that it may be useful in the differential diagnosis of unruptured ovarian cysts from adnexal torsion (20).

Hematological parameters have also been studied in patients with testicular torsion. Gunes et al. reported significantly high sensitivity and specificity for the NLR in the prediction of testicular torsion diagnosis (21). NLR has been found to be associated with the duration of symptoms and may be used as a predictive factor for testicular viability following testicular torsion.

Platelets, whose primary function is hemostasis, are also known to play a role in the inflammatory process (22). MPV, a routine parameter of complete blood count, demonstrates platelet size and activity. It represents not only platelet activation but also systemic inflammation and infection. In cases of acute inflammation and thrombosis, platelet production and activation increases, and the increase in platelets is especially seen in young and large platelets. Large platelets are known as stress platelets. This situation causes an increase in MPV levels. As result of the migration of a majority of the large reactive platelets to inflammatory sites, where they are consumed, and MPV levels decrease (23). Pro-inflammatory cytokines and acute phase markers secreted in the inflammatory process may cause reduction in platelet volume by suppressing megakaryopoiesis in the bone marrow (24).

Although conflicting results exist in the literature that link both increased and decreased MPV to inflammation, evidence particularly derived from prospective trials proposes an increase in MPV with a risk of thrombosis and low grade inflammatory conditions. High grade inflammatory diseases, such as active rheumatoid arthritis, acute pancreatitis and adnexal torsion, 
are commonly reported to be present with low MPV levels $(18,25,26)$. In our study, the MPV levels in patients with ovarian torsion were found to be statistically significantly lower than the control group. MPV was an independent predictor of preoperative ovarian torsion diagnosis and determined an optimal cut-off value of $10.35 \mathrm{fL}$, with $77.4 \%$ sensitivity and $74.2 \%$ specificity.

The NLR and MPV are easily measured laboratory markers used to evaluate systemic inflammation, but these markers can be associated with many conditions. Chronic diseases such as hypertension, diabetes mellitus, malignancy and chronic inflammatory diseases may affect NLR and MPV levels, these conditions should be taken into account when evaluating these parameters.

The retrospective nature of the study is a limiting factor. Another limitation of the present study is relatively small sample size. Also we did not include patients with ruptured ovarian cysts in our study.

The present study demonstrated increased NLR and decreased MPV values in patients with ovarian torsion. These results suggest NLR and MPV as an accessible, predictive parameters in relation to ovarian torsion. We think that beside a careful preoperative evaluation including clinical characteristics, ultrasonographic features, NLR and MPV may be used for prediction of ovarian torsion in patients with acute abdominal pain.

\section{CONCLUSION}

The parameters, NLR and MPV, together with other inflammatory markers can provide additional information about the diagnosis of patients with ovarian torsion and preoperative differential diagnosis from other acute abdomen cases.

Acknowledgments: None.

Conflict of Interest: No conflict of interest was declared by the author.

Financial Disclosure: The author declared that this study has received no financial support.

\section{REFERENCES}

1. Huchon C, Fauconnier A. Adnexal torsion: a literature review. Eur J Obstet Gynecol Reprod Biol 2010; 150:8-12.

2. Hibbard LT. Adnexal torsion. Am J Obstet Gynecol 1985; 152:456-61.

3. Sasaki KJ, Miller CE. Adnexal torsion: review of the literature. J Minim Invasive Gynecol 2014; 21(2):196-202.
4. Wilkinson C, Sanderson A. Adnexial torsion multimodality imaging review. Clin Radiol 2012; 67:476-83.

5. Robertson JJ, Long B, Koyfman A. Myths in the evaluation and management of ovarian torsion. J Emerg Med 2017:52:449-56.

6. Gerscovich EO, Corwin MT, Sekhon S, Runner GJ, Gandour-Edwards RF. Sonographic appearance of adnexal torsion, correlation with other imaging modalities, and clinical history. Ultrasound Q 2014; 30:49-55.

7. Huang $C$, Hong MK, Ding DC. A review of ovary torsion. Tzu Chi Medical Journal 2017; 29(3):143-7.

8. Kahramanca S, Ozgehan G, Seker D, Gokce El, Se$\operatorname{ker} G$, Tunc $G$, et al. Neutrophil-to-lymphocyte ratio as a predictor of acute appendicitis. Ulus Travma Acil Cerrahi Derg 2014; 20:19-22.

9. Akopuz A, Turan V, Ozcan A, Kopuz Y, Toz E, Kurt S. A novel marker for the assessment of the treatment result in pelvic inflammatory disease. Minerva Ginecol 2016; 68(2):11723.

10. Incebiyik A, Seker A, Vural M, Gul Hilali N, Camuzcuoglu A, Camuzcuoglu H. May mean platelet volume levels be a predictor in the diagnosis of pelvic inflammatory disease? Wien Klin Wochenschr 2014; 126:422-6.

11. Yildirim MA, Seckin KD, Togrul C, Baser E, Karsli MF, Gungor T, et al. Roles of neutrophil/lymphocyte and platelet/ lymphocyte ratios in the early diagnosis of malignant ovarian masses. Asian Pac J Cancer Prev 2014; 15:6881-5.

12. Celikbilek M, Dogan S, Ozbakir O, Zararsiz G, Kucuk $\mathrm{H}$, Gursoy $\mathrm{S}$, et al. Neutrophil-lymphocyte ratio as a predictor of disease severity in ulcerative colitis. J Clin Lab Anal 2013; 27:72-6.

13. Yilmaz E, Bayram Kacar A, Bozpolat A, Zararsiz G, Gorkem BS, Karakukcu M, et al. The relationship between hematological parameters and prognosis of children with acute ischaemic stroke. Childs Nerv Syst 2018; 34: 655-61.

14. M Nissen, V Sander, P Rogge, M Alrefai, R-B Tröbs. Neutrophil-to-lymphocyte ratio and platelet-to-lymphocyte ratio may predict pediatric ovarian torsion: A mono-institutional experience and review of literature. J Pediatr Adolesc Gynecol 2020; S1083-3188(20)30399-5.

15. Zhao Z, Zhao X, Lu J, Xue J, Liu P, Mao H. P r o g nostic roles of neutrophil to lymphocyte ratio and platelet to lymphocyte ratio in ovarian cancer: a meta-analysis of retrospective studies. Arch Gynecol Obstet 2018; 297(4):849-57. 
16. Kang Q, Li W, Yu N, Fan L, Zhang Y, Sha M, et al. Predictive role of neutrophil-to-lymphocyte ratio in preeclampsia: A meta-analysis including 3982 patients. Pregnancy Hypertens 2020; 20:111-8.

17. Kakhki RD, Dehghanei M, ArefNezhad R, Motedayyen $\mathrm{H}$. The Predicting Role of Neutrophil- Lymphocyte Ratio in Patients with Acute Ischemic and Hemorrhagic Stroke. J Stroke Cerebrovasc Dis 2020; 29(11):105233.

18. Tas EE, Keskin HL, Kir EA, Kilic G, Cetinkaya G, Yavuz AF. Can preoperative complete blood count parameters be used in the diagnosis of patients with adnexal torsion: a case-control study. J Pak Med Assoc 2020; 70(8):1319-23.

19. Ercan Ö, Köstü B, Bakacak M, Coşkun B, Tohma A, Mavigök E. Neutrophil to Lymphocyte ratio in the diagnosis of adnexal torsion. Int J Clin Exp Med 2015; 8(9):16095-10.

20. Soysal S.,Baki R. Diagnostic value of neutrophil to lymphocyte ratio in differentiation of ruptured ovarian cysts and adnexal torsion Türk J Obstet Gynocol 2018; 15(2):91-4.
21. Gunes M, Umul M, Altok M, Akyuz M, İsoglu CS, Uruc $F$, et al. Predictive role of hematologic parameters in testicular torsion. Korean J Urol 2015; 56:324-9.

22. Park Y, Schoene N, Harris W. Mean platelet volume as an indicator of platelet activation: methodological issues. Platelets 2002; 13:301-6.

23. Balta S, Demirkol S, Unlu M, Celik T. Other inflammatory markers should be kept in mind when assessing the mean platelet volume. Platelets 2014; 25:552-3.

24. Lei JJ, Zhou L, Liu Q, Xiong C, Xu CF. Can mean platelet volume play a role in evaluating the severity of acute pancreatitis? World J Gastroenterol 2017 Apr 7;23(13):2404-13.

25. Kisacik B, Tufan A, Kalyoncu U, Karadag O, Akdogan A, Ozturk M.A, et al. Mean platelet volume (MPV) as an inflammatory marker in ankylosing spondylitis and rheumatoid arthritis. Joint Bone Spine 75 (2008), pp. 291-4. 